munication from one of us $^{14}$, it is essential to overcome it if the porometer is to be used other than to show in a purely qualitative manner whether the stomata are opening or closing. The ideal to aim at is obviously to make the conditions within the cup the same as those outside. This has been to a large extent achieved by a simple modification of the form of resistance porometer used by Heath ${ }^{4}$. Air of the same composition and humidity as that surrounding the leaf is supplied to the porometer at a constant increased pressure by a simple aspirator working on the 'gasometer' principle. To avoid alteration of the humidity, medicinal paraffin is used in the aspirator and a light grade of the same in the manometers. As compared with the normal type of resistance porometer the pressure gradients are all reversed, but the manometer readings are used in the usual way, only the signs being changed. A hole in the glass or 'Perspex' plate pressing the leaf against the cup washer leaves all the upper leaf surface above the cup area open to the air. Between readings the cup is swept with a stream of the same air that surrounds the rest of the leaf, and during readings such air is being forced from the cup into the leaf through the stomata. There is therefore no tendency for water vapour or other gaseous substances from the leaf to accumulate in the cup. Using this modification of the porometer, preliminary tests with Pelargonium have indicated that the stomal apertures inside and outside the cup, as shown by Lloyd's method, are of similar magnitude. A preferable alternative to sweeping air through the cup would be the use of a detachable cup. Maskell?, using the smooth-leafed cherry laurel, was able to use a cup with a gelatine washer which was simply pushed against the leaf and could be completely removed between readings. For hairy leaves such as Pelargonium, however, it is necessary to use a special design of detachable cup which leaves the washer in position on the leaf between readings. Such cups have been used previously for Pelargonium in the Research Institute of Plant Physiology, and the method is at present in use in experiments with wheat. A similar cup will now be tried with Pelargonium, which is easier than wheat to examine by Lloyd's method, to see whether it gives similar apertures within and outside the cup area.

It is likely that with readings of short duration a normal (reduced pressure) resistance porometer might safely be used; but the modification described above reduces the risk and does not appear to have any disadvantages. The 'gasometer' type of aspirator, which can, of course, be used for either increased or reduced pressures, has the important advantage over the usual type that there is no bubbling of the air through a liquid and hence the menisci in the manometers are absolutely steady and readings can be made instantaneously.

It should be emphasized that data obtained with the more usual type of porometer and a permanently fixed unswept cup are valid for the enclosed stomata so far as qualitative indication of opening or closure in response to light or darkness is concerned. The stomata within the cup do respond to light, and open much wider than those outside. It may be noted also that when used with double 'leaf chambers's, in which a considerable area outside the porometer cup is maintained under identical conditions, the normal type of porometer yields data which as an approximation at least may be treated quantitatively in the manner indicated elsewhere 4 .
This work is continuing and will be published in detail in due course.

Research Institute of Plant Physiology, O. V. S. Heath

Imperial College, London, S.W.7.

$$
\text { W. T. WrLIIAMs }
$$

Botany Department,

Bedford College for Women, London, N.W.1.

${ }^{1}$ Darwin, F., and Pertz, D. F. M., Proc. Roy. Soc., B, 84, 136 (1911). ' Knight, R. C., New Phyt., 14, 212 (1915).

- Gregory, F. G., and Pearse, H. L., Proc. Roy. Soc., B, 114, 477 (1934).

'Heath, O. V. S., Ann. Bot., N.S., 5, 455 (1941).

-Gregory, F. G., and Pearse, H. L., Ann. Bot., N.S., 1, 3 (1937).

- Williams, W. T., Ph.D. Thesis, Univ. Lond. (1940).

' Maskell, E. J., Proc. Roy. Soc., B, 102, 488 (1928).

Beath, O. V. S., Ann. Bot., N.S., 3, 469 (1939).

- Gregory F. G., and Armstrong, J. I., Proc. Roy. Soc., B, 121, 27 (1936).

${ }^{10}$ Penman, H. L., Proc. Roy. Soc., B, 139, 416 (1942).

11 Williams, W. T., Nature, 160, 364 (1947).

${ }^{12}$ Lloyd, F. E., Pub. Carneg. Inst., 82 (1908).

${ }_{13}$ Molisch, H., Z. Bot., 4, 106 (1912).

14 Heath, O. V. S., following communication.

\section{Control of Stomatal Movement by a Reduction in the Normal Carbon Dioxide Content of the Air}

To account for the much wider stomatal apertures found within a porometer cup than elsewhere on an illuminated leaf ${ }^{1}$, the hypothesis was examined that some volatile substance produced by the leaf itself caused opening of the stomata in light when in high concentration. On testing this hypothesis a considerable amount of experimental evidence was obtained in its favour. Thus detached leaves in water of Pelargonium or wheat, enclosed together with entire plants in a saturated atmosphere under a bell jar and illuminated for a few hours, showed wide stomatal opening when tested by the injection technique of Williams ${ }^{1}$; single leaves similarly enclosed by themselves, also in a saturated atmosphere and illuminated, showed little or no injection. On the other hand, similar single leaves of wheat each enclosed in a small volume of saturated air in a glass tube showed very heavy injection, as in the leaves from the crowded bell jars. When such tubes were swept continuously with a slow stream of humid air, little or no injection of the leaves was found.

The following statistically significant effects were thus obtained : (1) Heavier injection (wider stomatal opening) with many than with few or single leaves in the same large volume of humid still air ; (2) heavier injection with single leaves in a small than in a large volume of humid still air ; (3) heavier injection with single leaves in a small volume of humid still air than in humid moving air. Porometer experiments with Pelargonium showed that sweeping the cup with moving air, whether dry or humid, caused considerable stomatal closure as compared with still air. Similar results have been obtained with wheat, using dry air, by Mr. Milthorpe in this Institute. Darwin's finding that removal of plants from a (presumably crowded) greenhouse to the laboratory caused stomatal closure, but that enclosure of the plants in bell jars caused the stomata to remain open or re. open, also seemed to support the hypothesis, although he himself attributed these effects to humidity changes.

There existed, however, the seemingly remote possibilities that all these effects were due either to 
the removal of carbon dioxide or the increase of oxygen concentration brought about by photosyn. thesis. The crucial experiments were therefore performed of sweeping porometer cups, attached to illuminated leaves of Pelargonium and wheat, with either carbon dioxide-free or ordinary air, both dry and humid conditions being investigated. It was at once found that moving carbon dioxide-free air, whether humid or dry, caused stomatal opening, sometimes even where the full opening in still air had been reached. This last implies sensitivity to extremely low carbon dioxide concentrations. Ordinary air at the same rate of flow caused very considerable closure. Rate of sweeping had virtually no effect between one and eight litres per hour (Pelargonium), and four litres per hour was adopted as standard. The effects of carbon dioxidefree and ordinary moving air in the dark were also investigated (Pelargonium). It was found that although carbon dioxide-free air would prevent complete closure in darkness and would also cause partial further opening of stomata which were not completely shut, if the stomata had been completely closed (resistance approx. infinity) by ordinary air they would not reopen in carbon dioxide-free air. This would seem to show that the effect of carbon dioxide is due to its concentration in the sub-stomatal cavities and not at the outer surface of the guard cells. In all these porometer experiments the modified resistance porometer ${ }^{1}$ was used ; the stomata were allowed to attain their equilibrium opening for each set of conditions before the conditions were altered, except in a few cases with saturated air, in which equilibrium was attained much more slowly than with dry air.

Supporting evidence for the 'carbon dioxide' hypothesis has been obtained from experiments in which single detached leaves of Pelargonium or wheat have been enclosed under bell jars, with or without a dish of $2 \mathrm{~N}$ caustic soda solution, and illuminated for a few hours. Significantly heavier injection has been found for both species in the leaves from the bell jars with caustic soda, the effect being particularly striking with Pelargonium.

The porometer experiments not only dispose of the 'volatile substance' hypothesis, for such a substance should be equally swept away by either carbon dioxide-free or ordinary air ; they similarly dispose of the 'oxygen' hypothesis. The only remaining possibility, apart from a carbon dioxide effect, seems to be that closure is caused by some other substance present in the air supply Such a substance would have to be absorbed by caustic soda or soda lime but not by silica gel, phosphorus pentoxide or calcium chloride; nor by a solution of sodium thiosulphate, which was used to remove chlorine from humid air supplied by a water pump. Furthermore, such a substance must be of wide occurrence, for similar partial closure of stomata freely exposed to the air has been found at Bedford College $e^{1,3}$ and in two laboratories in the Research Institute ${ }^{1}$. In the latter there was no gas supply nor tobacco smoke. On the present evidence, therefore, the 'carbon-dioxide' hypothesis seems by far the most plausible.

The effects of carbon dioxide on stomata have been investigated in a sporadic manner for more than fifty years, but the comparison has almost always been made between carbon dioxide-free or ordinary air and very high concentrations or even pure carbon dioxide. Darwin', using his 'horn hygroscope', found that the stomata in light "remain open in an atmosphere free from carbon dioxide". In pure carbon dioxide they were found to close slowly. $\mathrm{He}$ criticized Schellenberger's ${ }^{4}$ finding, that in carbon dioxide-free air the stomata closed slowly, as being due to the use of relatively dry air; but the present work renders this explanation improbable, and many other factors, such as a diurnal rhythm of stomatal movement ${ }^{5,6}$, may have been involved. Lloyd's ${ }^{7}$ data for Verbena ciliata rather suggest that the stomata do not close readily in darkness in carbon dioxide. free air, but if already shut will remain closed; in light they open in carbon dioxide-free air. These results resemble some of the present findings but Lloyd does not direct attention to them. Linsbauer ${ }^{8}$ investigated the effects of carbon dioxide-free air both in light and darkness, and found that in all experiments the removal of carbon dioxide favoured the opening of stomata in the dark. The effect in the light was stated to be the same but less pronounced owing to the stomata being already partly open. These entirely correct results have seemed suspect owing to the very crude technique by which they were obtained, for leaf fragments were held against a moist filter paper over solid caustic potash or a strong solution, and Linsbauer himself noted that the tendency of the leaf fragments to dry gave much trouble. High carbon dioxide concentrations were found to cause closure or failure to open in both light and darkness. Stahl ${ }^{9}$ also found that high carbon dioxide concentration caused closure. Scarth ${ }^{10}$ in. vestigated the effects of high concentrations of carbon dioxide (10-50 per cent) and found in darkness closure followed after many hours by opening. In the light, opening was prevented. Carbon dioxide. free air was apparently not investigated.

The importance of the findings here reported would seem to lie in the discovery of the extreme sensitivity of the stomata to very small variation in carbon dioxide concentration (between c. 0.03 per cent and zero). This is found to furnish a plausible explanation of a number of hitherto obscure phenomena observed in the course of many years research on stomata in this Institute. Such a mechanism may well have the biological advantage for the plant that the stomata tend to close in wind and thus reduce the risk of desiccation due to excessive transpiration. That such stomatal control of transpiration in wind can occur is shown by moving air experiments at present in progress in this Institute, and is strongly suggested by the work of Wrenger"1.

The present work argain raises the possibility that the light response of the stomata may be entirely due to the removal of carbon dioxide by photosynthesis, and the dark response to its accumulation inside the leaf, as has been suggested by Stahl ${ }^{9}$, Sayre $^{12}$, Scarth ${ }^{13}$ and others. Clearly, however, not only the carbon dioxide of respiration but the external supply also is of great importance, especially in the light, and much further work is needed.

The mechanism by which the carbon dioxide con. centration controls movement of the guard cells also calls for much further investigation. The opening force in the stoma nas been snown to be supplied ultimately by the turgor of the guard cells ${ }^{14}$, but the intermediate steps between this and the carbon dioxide concentration in the substomatal cavity are quite uncertain. The evidence for the usual starch $\rightleftarrows$ sugar hypothesis, whether controlled through $p H$ change or in any other way, is not convincing so far as the dark-light response is concerned ${ }^{15}$. 


\section{No. 4083 January 31, $1948 \quad$ N A T U R E}

This work will be continued and detailed publication will follow in due course.

O. V. S. Heath

Research Institute of Plant Physiology,

Imperial College, London, S.W.7.

${ }^{2}$ Heath, O. V. S., and Williams, W. T., previous communication

${ }^{2}$ Darwin, F., Phil Trans. Roy. Soc., B, 190, 531 (1898).

' Williams, W. T., Nature, 160, 364 (1947).

' Schellenberger, Bot. Z., 169 (1896).

${ }^{5}$ Maskell, E. J., Proc. Roy. Coc., B, 102, 488 (1928).

'Gregory, F. G., and Pearse, H. L., Ann. Bot., N.S., 1, 3 (1937).

'Lloyd, F. E., Pub. Carneg. Inst., 82 (1908).

'Linsbauer, K., Flora, N.F. 9, 100 (1916).

- StahI, E., Flora, N.F., 13, 1 (1919)

- Scarth, G. W., Plant Physiol., 7, 481 (1932).

"Wrenger, M., $Z$. Bot., 29, 257 (1935).

${ }^{12}$ Sayre, J. D., Ohio J. Sci., 26, 233 (1926).

${ }^{15}$ Searth, G. W., Proc. Int. Cong. Plant Sci., 2, 1151 (1929).

${ }^{11}$ Heath, O. V. S., New Phyt., 37, 385 (1938).

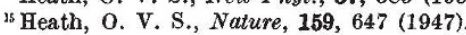

\section{SOCIAL AND SCIENTIFIC DEVELOPMENT OF THE WEST INDIES}

$\mathrm{T}$ HE considerable report by Sir John Macpherson, recently issued*, contains much valuable information relating to the work of the Develooment and Welfare Organisation in the West Indies. The report at once conveys an impression of how much is being done (or is under consideration) and how much there is yet to do. The contemporary situation in the West Indian Colonies, whether agricultural, economic, social or political, is complex. It has been long in the making, and wise foresight, good management, patience, industry and optimism will be needed before matters are put right. It is probably true to say that, in this region, there is now a general demand for conditions which will enable the local populations to enjoy a fuller and better life. In practice this means that improvements must be effected in almost every walk of life and in every branch of official activity.

The report opens with an informative general survey of West Indian affairs. Particular attention is given to such topics as agriculture, forestry, fisheries, education, public health, housing, town planning, labour conditions, social welfare, public works, etc. A special Welfare Fund, granted by the Exchequer of the United Kingdom, is available for promoting schemes for the general improvement of education, health services, land settlement, and the hundredand-one projects which collectively will make for better conditions and opportunities for the native population of the West Indies.

Space does not admit of an adequate review of the contents of this report. But as an example of the treatment accorded to one major theme, agriculture may be selected. Here, as elsewhere, Sir John is direct and to the point. It is most sincerely to be hoped that his words will be heeded throughout the length and breadth of our Caribbean Colonies. The ideas are not new, but it is good to hear them forcibly restated at this time :

"The greatest need of the British West Indies to-day is the most intensive use of the land according to methods of good husbandry, both for export crops and local food crops. In no other way can a growing population be supported or the demands for higher

* Development and Welfare in the West Indies. By Sir John Macpherson. Col. 212. Pp. 162. (London: H.M. Stationery Office 1947). 38 . standards of living be met. The intensive and balanced use of the land calls for far-reaching reforms in the basic methods now employed, and for improved education facilities and efficient adviscry services. The reforms require special measures, some of which cannot be successfully applied until new knowledge acquired through scientific investigation has been made widely available. The work of the Development and Welfare organisation has been constantly guided by these fundamental facts."

It is heartening to read that the need for soil conservation is being more widely understood, that grass is being introduced as a rotational crop, and that there is an increasing disposition to realize that land, water and forest resources are "the foundation upon which better standards of life can be established".

As improvement in agriculture will necessarily depend on an advance in agricultural education, measures to achieve this end are in hand. Measures to assist peasant agriculture, to promote mixed farming adapted to West Indian conditions, to test communal and co-operative farming, and to improve livestock, etc., each has its place in the new agric. ultural outlook. The essential place of a wide system of researches, duly co-ordinated, is recognized. This matter has been given much attention, and a number of schemes have already been approved. Some of these, including problems of sugar technology, soil science, the improvement of cacao, genetics of tropical crops, including bananas, etc., will be centred at the Imperial College of Tropical Agriculture in Trinidad, while related investigations will be carried out in some of the other islands because of their special suitability for the work.

These notes give but a small sample of the contents of this document as they relate to agriculture. Attention is also given, in due measure, to the several other major topics mentioned above. The text, clearly but closely written, contains much interesting and valuable detail and should be carefully read by all who follow with interest and sympathy the new movement that is undoubtedly afoot in the Colonies.

\section{FORTHCOMING EVENTS}

(Meetings marked with an asterisk * are open to the public)

Monday, February 2

FARMERS' CLUB (at the Royal Empire Society, Craven Street, London, W.C.2), at 2.30 p.m.-Dr. W. G. Ogg : "Soil and the Farmer".

ROYA4 SOcIETY OF ARTs (at John Adam Street, Adelphi, London, W.C.2), at 4.30 p.m.- -Prof. A. C. Frazer : "The Metabolism of Fats", (Cantor Lecture).

INSTITUTION OF POST OFFICE ELECTRICAL ENGINEERS (at the Institution of Electrical Engineers, Savoy Place, Victoria Embank ment, London, W.C.2), at 5 p.m.-Dr. D. G. Tucker and Mr. F. Scowen 'Modern Approach to Transmission Networks"

SocIETr of ENGINERrs (at the Geological Society, Burlington House, Piccadilly, London, W.1), at 5.30 p.m.-Mr. E. E. Turner Presidential Address.

Tuesday, Febiruary 3

UNIVERSITY COLJEGE LONDON (in the Anatomy Theatre, Gower Street, London, W.C.1), at 1.15 p.m.-Prof. L. S. Penrose : "Human Genetics".

BRITISH SOOIETY FOR INTERNATIONAI BIBLIOGRAPHY (at the Institution of Electrical Engineers, Savoy Place, Victoria Embankment, London, W.C.2), at 2.30 p.m.-Papers.

ROYAL ANTHRopological INSTITUTE (at 21 Bedford Square ROYAL ANTHROPOLOGICAL INSTITUTE (at 21 Bedford Square,
Iondon, W.C.1), at 5 p.m.-Rev. Prof. E. O. James: "The Social Function of Anthropology".

ROYAT STATISTICAL SOCIETY, RESEARCH SECTION (at the London School of Hygiene and Tropical Medicine, Keppel Street, London, W.C.1) at 5.15 p.m.-Mr. W. L. Stevens : "Control by Gauging".

Conway Discussion Circie (at Conway Hall, Red Lion Square London, W.C.1), at 7 p.m.-Dr. J. A. C. Brown:' 'Group Psychology in Industry" 